\title{
SPEECH ACT EXPRESSIONS IN THE ADVERTISEMENTS ON TELEVISION: \\ A Case Study of Three Advertisements Both Food \& Health Products and Cell-Phone Provider
}

\author{
Puspita Halim \\ Universitas Widyatama \\ E-mail:pithahalim@yahoo.com
}

\begin{abstract}
The study entitled "Speech Act Expressions in the Advertisements on Television: A Case Study of Three Advertisements Both Food \& Health Products and Cell-phone Provider" seeks to illuminate the types of speech acts based on Searle (1979) and the approaches of advertisements proposed by Book and Schick (1996). This study mainly uses a qualitative method to analyze the collected data in this research. The data sources are in the form of verbal texts, namely, statements of the speaker's dialogue and narration both Food \& Health Product and cell-phone provider advertisements. These advertisements were taken from several private TV stations aired during $1^{\text {st }}$ March $-30^{\text {th }}$ April 2010. The three advertisements were selected and categorized into four styles, namely, dramatizations, demonstrations, presentations, and testimonials. These commercials were classified into three tones, namely, factual, emotional, and humorous. Furthermore, the research was conducted to investigate the types of speech acts expressed in these different styles and tones of advertisements, namely representatives, directives, commissives, expressive, and declaratives. The study has discovered three tones within testimonial, demonstration, and presentation styles. Furthermore, it has exposed one emotional tone within presentation style. And two factual tones within testimonial and demonstration styles. This research has obtained linguistic notion and comprehension for students who are engaged in learning speech act expression in several utterances, mainly advertisements.
\end{abstract}

Keywords: speech act, advertisement, style, tone

\section{Introduction}

Nowadays, the growth of advertisement increasingly becomes a significant industry. A highly competitive business environment in which companies struggle to surge has triggered the fast growth and development of advertisement ahead by using their advertising campaigns in both print and electronic media.

Today, advertisers are competing hard in order to grab the biggest audience to achieve their goals, that is, to sell their product to consumers. There are many advertisements on television that attract people in the world, such as cosmetic and cell-phone provider 
advertisements. They try to persuade people to buy a particular product and to believe in its special quality.

In general, speech acts are acts of communication. To communicate is to express a certain attitude, and the type of speech act being performed corresponds to the type of attitude being expressed.

There are different tones and styles of advertisements in which the speech acts expressed, namely, dramatization, demonstration, presentation, and testimonial (Book and Schick, 1996). In this study, the focus was given to the types of speech acts found in the advertisements on television, relating to those three specific tones four different styles of advertisement.

As the tones and styles are the major concern in copy writing, the study can give us knowledge about types of speech acts as well as tones and styles of advertisements. More specifically, this knowledge can contribute to copy writers in the creation of advertisements on television in more various and effective ways

This study employs Searle theory to search types of speech acts in the different styles of advertisement on television because there is further explanation, which is explored by Yule (1996). One general classification system lists five types of general functions performed by speech acts: "declarations, representatives, expressive, directives, and commisives (Yule 1996)".

Table 2.1 The five general functions of speech acts (following Searle 1979)

\begin{tabular}{|l|l|l|}
\hline Speech act type & Direction of fit & $\begin{array}{l}\text { S = speaker; } \\
\text { X = situation }\end{array}$ \\
Representatives & Words change the world & S causes X \\
Expressives & Make words fit the world & S believes X \\
Directives & Make words fit the world & S feels X \\
Commissives & Make the world fit words & S wants X \\
& Make the world fit words & S intends X \\
\hline
\end{tabular}

Kleppner (1986) says that "the existing and potential variation of TV as a source of information, entertainment and interactive services, force us to consider that TV as a communication and advertising medium, in a number of ways". 
Burgoon and Ruffner (1974), persuasive communication is a conscious attempt by one individual to modify the attitudes, beliefs, or behavior of another individual or group in individuals through the transmission of some messages??

As matter of fact, the tone of an advertisement can be factual, emotional, and humorous (Book and Schick, 1996). With a factual approach, advertising presents the facts in a more or less straightforward manner.

In terms of style - or how the advertisement is presented - Book and Schick (1996) classify styles of advertisement into four options:

a. Dramatization. A dramatization or story is usually either emotional or humorous. It can stimulate desire or create interest by evoking a particular mood, such as nostalgia, togetherness, or escapism. This approach is also called a "narrative".

b. Demonstration. A demonstration, usually factual in tone, shows how the product or service is used. It might consist of a description of step-by-step operation of the product.

c. Presentations. In a presentation, the features or benefits of the product are presented or described rather than dramatized or demonstrated.

d. Testimonials. Testimonials are presentations in which the presenter describes his or her firsthand experience with the product. This approach can be effective if the testimony is believable.

\section{Research Methodology}

A qualitative approach was selected for the reason that the study is aimed to understand the meaning of advertisement messages through speech acts to understand the context and to develop causal explanation. Since this study seeks to understand speech act expressions in the advertisements on television, Best (1993: 125) states that "a descriptive method is a method of research that describes and interprets what it is in order to answer questions in coping with the current status of the subject". By using such a descriptive method, this study aims to describe the facts about the object of the research, namely, the use of speech acts in advertisements on television.

\section{Data Sources}

Food \& health product and cell-phone provider advertisements have been chosen as the population of the research. The data of the research are in the form of verbal texts such as 
illustration and statements of the speakers' conversations. Speech act expressions appear clearer in verbal form or conversation context than in non-verbal form because it is supported by speaker's expression, intonation, and motion picture. The data sources of this study include two food \& health products and cell-phone provider advertisements. They are selected because they have highly frequent broadcast and seem to have tight competition in sponsoring a number of TV programs observed from four big private TV stations, namely, RCTI, SCTV, TRANS TV and INDOSIAR during $1^{\text {st }}$ March $-30^{\text {th }}$ April 2010.

\section{Sample and Technique of Sampling}

This study has employed purposive sampling to discover, understand, and obtain insight (Merriam, 1998, p. 48). The samples have several criteria, namely, those advertisements express four styles (dramatization, demonstration, presentation, and testimonial) and three tones (factual, emotional, and humorous), in which types of speech acts occurred. Based on the criterion, there are two food \& health products advertisements and one cell-phone provider advertisements.

\section{Data Collection}

The advertisements were recorded in order to investigate the messages accurately and precisely. The cell-phone recording data were played over and over in order to do accurate analysis and to minimize the risk of losing a part of the data such as words, phrases, or sentences that are needed.

In further detail the process includes (a) recording each of the three advertisements. using cell-phone recorder during $1^{\text {st }}$ March $-30^{\text {th }}$ April 2010, (b) transcribing the conversation of these advertisements, (c) analyzing the transcripts of the conversation by using speech act theory and then pointing out this into a descriptive text, (d) checking each of the advertisements carefully to find speech act in their conversation, and (e) classifying the advertisements that contain types of speech act according to Searle, namely representatives, commissives, directives, expressive, and declaratives.

\section{Data Analysis}

The collected data, namely, food \& health products and cell-phone provider advertisements were categorized into three tones and four styles of advertisements based on Book and Schick (1996) theories: 
a. Tones of Advertisements: Factual, emotional, humorous,

b. Styles of Advertisements: dramatizations, demonstrations, presentations, testimonials.

Subsequently, the analysis was constructed by determining the types of speech acts according to Searle in those advertisements on television. There are five types of speech acts based on Searle (1979) perspective: representatives, directives, expressive, commissives, and declaratives. The tones and styles of advertisements and types of speech acts mentioned above are classified in tables. These tables are applied in the further findings and discussions to reveal the numbers of advertisement tones and styles as well as speech acts types.

\section{Results and Discussions}

\section{The Tones and Styles of Advertisements}

This study presents the three advertisements comprising two food $\&$ health products and cellphone providers and are categorized into three tones and four styles based on Book and Schick's point of view (1996). The tones are classified into three categories, namely, factual, emotional, and humorous; and styles into four categories, namely, dramatization, demonstration, presentation, and testimonial. The tones and styles of the seven advertisements are shown in the following table:

Table 3.1 Food \&Health Products and Cell-phone Provider advertisements that are categorized into tones and styles

\begin{tabular}{|c|c|c|c|}
\hline Products & Advertisements & $\begin{array}{c}\text { Tones of } \\
\text { Advertisements }\end{array}$ & Styles of Advertisements \\
\hline Food \& Health Products & Mie gelas & Factual & Testimonial \\
\cline { 2 - 4 } & Garglin & Factual & Demonstration \\
\hline Cell-phone Provider & IM3 (T.R.I.A.D's version) & Emotional & Presentation \\
\hline
\end{tabular}

The table 3.1 illustrates that the three advertisements are categorized into the three tones and the three styles. From the categorization, this research found one testimonial styles using factual tone, one demonstration styles using factual tone, and one presentation styles using emotional tone. The subsequent are the further analyses of tones and styles in the three advertisements on television. The analyses are described by grouping the three advertisements based on two categories, namely, food $\&$ health products and cell-phone provider advertisements. 


\section{Food \& Health Products Advertisements}

\section{1). Mie gelas}

A testimony from a man:

Kenapa mie gelas jadi nomor satu buat mereka?

Karena besar gizinya, protevit.

Praktis, tinggal seduh.

Hmmm...buat saya pas porsinya.

The narrator's utterances:

Mie gelas satu buat semua.

Mie gelas lebih dari mie dalam gelas.

Mie gelas was a food product that gives the nutrition, that is, protevit and practical to be served. This advertisement is categorized into a factual because it shows the fact in a more or less straightforward manner. The goal of this advertisement was to inform about a distinctive product feature and become number 1 (an obvious consumer benefit), that is, this product contains protevit to provide the enormous nutrition for the consumers.

The style of this advertisement is a testimonial. The speaker presents firsthand experience with Mie gelas. This product is appropriate for the speaker's portion. A testimonial can be effective if the testimony is believable.

\section{2). Garglin}

The narrator's utterances:

\footnotetext{
Mulut kita banyak mengandung kuman,

sakit tenggorokan, kuman sariawan.

Kumur dengan Garglin.

Garglin cara cepat membunuh kuman.

Cepat loh $1-2$ hari sakit hilang.

Garglin cara cepat buang kuman.
}

Garglin was as an advertisement that offers a health product to customers that is beneficial to kill the germs in our mouth and to cure oral ulceration (sprue). The dialogue involves an experiencing woman. Garglin is classified into factual tone because it presents the facts in a more or less straightforward manner. This advertisement tells about the changes of our mouth as a fact, which is actually experienced by everyone.

The style of Garglin advertisement is a demonstration. It shows a general fact that is faced by people in the world. A demonstration, usually factual in tone, shows how the product or service is used (Book and Schick, 1996). 


\section{Cell-phone Provider Advertisement}

\section{1). IM3 (T.R.I.A.D's version)}

The narrator's utterances:

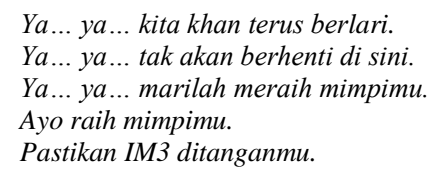

IM3 as a cell-phone provider offers a good network and expands it into almost every corner of the country. The IM3 advertisement is classified into an emotional tone because it can involve the customers by dwelling on feelings, such as, hopes, desires, and effective. This advertisement tries to attract the customers by expressing feelings of hopes and desires. The sentences "terus berlari"; "tak akan berhenti"; and "raih mimpimu" are all expressions of feeling. This advertisement has the purpose to persuade people to be users of this product. IM3 provides a good network and reduced price in order to communicate incessantly.

\section{The Types of Speech Acts in Advertisements}

There are some types of speech act in the advertisements. In point of view's Searle, five types of speech act, namely, representatives, directives, commissives, expressive, and declaratives, which are expressed in the seven advertisements both food \& health products and cell-phone providers (Searle:1979 in Cruse: 2000). These types of speech acts are shown in the two specific tones and four different styles of the seven advertisements.

\section{Food and Health Product}

\section{1). Mie Gelas}

The dialogue of Mie Gelas advertisement contains speech act expressions as shown in the following table:

Table 3.2. Types of Speech Acts in Mie Gelas Advertisement

\begin{tabular}{|l|l|}
\hline Types of Speech Acts & Advertisement Text \\
\hline Representatives & - Kenapa Mie Gelas jadi nomor satu buat mereka? \\
& - Mie Gelas satu buat semua. \\
& - Mie Gelas lebih dari mie dalam gelas. \\
\hline Directives & \\
\hline Commissives & - Karena besar gizinya, protevit. \\
\hline Expressives & - Praktis, tinggal seduh! \\
\hline
\end{tabular}




\begin{tabular}{|l|c|}
\hline & -Hmmm...buat saya pas porsinya! \\
\hline Declaratives & - \\
\hline
\end{tabular}

The speech act expressions in the commercial could be categorized into three types, namely, three representatives, a commissive, and two expressives. The first sentence "Kenapa Mie Gelas jadi nomor satu buat mereka?"; the second sentence“Mie Gelas satu buat semua"; the third sentence "Mie Gelas lebih dari mie dalam gelas" in the advertisement belong to three representatives types because they assert the truth of the expressed propotion. The speaker conveys what he experiences and believes to be case or not.

The fourth sentence "Karena besar gizinya, protevit" constitutes a commissive type because this product promises to give the enormous nutrient for our body. A commissive expresses what the speaker intends to promote this food product which is protevit for providing nutrient elements. The fifth sentence "Praktis, tinggal seduh!"; the sixth sentence "Hmmm...buat saya pas porsinya!" in the advertisement can be categorized into two expressives because they express a psychological state and a statement of satisfaction.

Table 3.3 shows the style and tone of advertisements and the percentage of speech act types expressed in the Mie Gelas advertisement.

Table 3.3. The Percentage of Speech Act Types in Mie Gelas Advertisement

\begin{tabular}{|c|c|c|c|c|}
\hline \multirow[t]{2}{*}{ Style } & \multirow[t]{2}{*}{ Tone } & \multirow{2}{*}{$\begin{array}{c}\text { Speech Act } \\
\text { Types }\end{array}$} & \multirow[b]{2}{*}{ Freq. } & \multirow[b]{2}{*}{$\%$} \\
\hline & & & & \\
\hline \multirow{5}{*}{ Testimonial } & \multirow{5}{*}{ Factual } & Representatives & 3 & 50 \\
\hline & & Directives & - & 0 \\
\hline & & Commissives & 1 & 16.66 \\
\hline & & Expressives & 2 & 33.33 \\
\hline & & Declaratives & - & 0 \\
\hline
\end{tabular}

\section{2). Garglin}

The dialogue of Garglin advertisement expresses three types of speech acts as shown in the following table. 
Table 3.4. Types of Speech Acts in Garglin Advertisement

\begin{tabular}{|l|l|}
\hline \multicolumn{1}{|c|}{$\begin{array}{c}\text { Types of Speech } \\
\text { Acts }\end{array}$} & \multicolumn{1}{c|}{ Advertisement Text } \\
\hline Representatives & -Mulut kita banyak mengandung kuman, sakit tenggorokan, kuman sariawan. \\
\hline Directives & -Kumur dengan Garglin. \\
\hline Commissives & -Garglin cara cepat membunuh kuman. \\
& - Cepat loh 1-2 hari sakit hilang. \\
& - Garglin cara cepat buang kuman. \\
\hline Expressives & \\
\hline Declaratives & \\
\hline
\end{tabular}

The table indicates three types of speech acts. The first sentence "in the advertisement "Mulut kita banyak mengandung kuman, sakit tenggorokan, kuman sariawan" belongs to a representative type because it asserts the truth of the expressed proposition. The speaker conveys what she experiences and believes to be case or not.

The second sentence of this advertisement "Kumur dengan Garglin" is a directive because the speaker gets someone else to do something. The statement expresses what the speaker wants. It commands or advises the customers to use this product.

A commissive commits the speaker to some future action (Yule:1996). Commissives are described in three statements shown in table 3.4. The three sentences mean that Garglin promises to make people's mouth free form germs quickly within 1-2 days. By commissives, the customers will be attracted in using this product. In using commissives, the advertisement undertakes to make the world fit the words via the speaker.

The Table 3.5 shows the style and tone of advertisements and the percentage of speech act types expressed in the Garglin advertisement.

Table 3.5. The Percentage of Speech Act Types in Garglin Advertisement

\begin{tabular}{|c|c|c|c|c|}
\hline \multirow[t]{2}{*}{ Style } & \multirow[t]{2}{*}{ Tone } & \multicolumn{3}{|c|}{ Speech Act } \\
\hline & & Types & Freq. & $\%$ \\
\hline \multirow{5}{*}{ Demonstration } & \multirow{5}{*}{ Factual } & Representatives & 1 & 20 \\
\hline & & Directives & 1 & 20 \\
\hline & & Commissives & 3 & 60 \\
\hline & & Expressives & - & 0 \\
\hline & & Declaratives & - & 0 \\
\hline
\end{tabular}




\subsubsection{Cell-phone Provider Advertisements}

\section{1). IM3 (T.R.I.A.D's version)}

The dialogue of IM3 advertisement expresses various types of speech acts (shown on Table 3.6).

Table 3.6. Types of Speech Acts in IM3 Advertisements

\begin{tabular}{|l|l|}
\hline Types of Speech Acts & Advertisement Text \\
\hline Representatives & $-Y a \ldots$ ya .. kita khan terus berlari. \\
& $-Y a \ldots$ ya .. tak akan berhenti di sini. \\
\hline Directives & - Ya . ya ... marilah meraih mimpimu. \\
& - Ayo raih mimpimu. \\
\hline Commissives & \\
\hline Expressives & \\
\hline Declaratives & - Pastikan IM3 ditanganmu. \\
\hline
\end{tabular}

The table indicates three types of speech acts expressed in the IM3 advertisement, namely, two representatives, two directives, and a declarative. The statement "Ya... ya... kita khan terus berlari" and "Ya... ya ... tak akan berhenti di sini" are two representatives. They express what the speaker believes to be case or not. The speakers have a belief toward the facts that they underwent. Two sentences "Ya.. ya... marilah meraih mimpimu" and "Ayo raih mimpimu" are two directives. These sentences express what the speaker asks.

The speaker gets someone else to do something. In this advertisement, the speaker suggests or orders the customers to make their dream true with IM3 provider. The sentence "Pastikan IM3 ditanganmu" is a declarative type. The speaker declares that IM3 is a cellphone provider, which the customers are sure to have it.

The Table 3.7 shows the style and tone of advertisements and the percentage of speech act types expressed in the IM3 advertisement. 
Table 3.7. The Percentage of Speech Act Types in IM3 Advertisement

\begin{tabular}{|c|c|c|c|c|}
\hline \multirow[t]{2}{*}{ Style } & \multirow[t]{2}{*}{ Tone } & \multicolumn{3}{|c|}{ Speech Act } \\
\hline & & Types & Freq. & $\%$ \\
\hline \multirow{5}{*}{ Presentation } & \multirow{5}{*}{ Emotional } & Representatives & 2 & 40 \\
\hline & & Directives & 2 & 40 \\
\hline & & Commissives & - & 0 \\
\hline & & Expressives & - & 0 \\
\hline & & Declaratives & 1 & 20 \\
\hline
\end{tabular}

\section{Conclusions and Suggestions}

In daily life, advertisements struggle to influence consumers by using different styles and tones. The study found that the three advertisements, based on Book and Schick's standpoint, can be classified into three styles, namely, one testimonial, one demonstration, and one presentation. Furthermore, these advertisements are classified into three tones, that is, one emotional and two factual tones. The various styles and tones in advertisements would seem to make copy-writers more innovative. The commercials will be more attractive and assorted.

Through the three advertisements, this research discovered two factual tones, namely, Mie Gelas, and Garglin. Through factual approach, the advertisements portray the facts in a more or less straightforward manner. Factual tones are expressed in testimonial, demonstration, and presentation styles.

A testimonial is presented in which presenter describes his or her firsthand experience with the product (i.e. Mie Gelas). Moreover, a demonstration illustrates how the product or service is used and a presentation depicts the features or benefits of the product. Based on Altstiel and Grow (2006), a demonstration has been effective in showing what a product can do (i.e. Garglin).

In addition, the emotional tone is found in one advertisement, IM3. As we are aware that people have something in common in emotions. The emotions can involve the customers' feelings of desires, and aspirations. The emotional tones are usually expressed in a presentation style (i.e. IM3). Thus, this study portrays the five types of speech acts, namely, representatives, directives, expressive, declaratives, and commissives are used in the advertisements. 
Representatives are expressed in the three advertisements, such as, Garglin and IM3. It happened because copywriter of some commercials considers that to assert the truth of expressed proposition is important, so that the advertisements have to describe what the speaker believes or experiences about the product to persuade customers.

Directives are exposed in Garglin, and IM3. These advertisements use directive speech acts to command, order, or request the customers to buy the products. As Reeves (adopted by Book and Schick: 1996) says that not just words, not just the product puffery, not just show-window advertising, each advertisement must say to the audiences "Buy this product, and you get this specific benefit".

In addition, expressive speech acts express psychological state. For instance, the statement "-Dan aku puaasss....and; Praktis, tinggal seduh! And "Hmmm...buat saya pas porsinya!" (Mie Gelas) express the feeling of satisfaction. From two advertisements, the expressive are only emerged in factual tone.

At last, declaratives are illustrated in IM3 in which the declaratives speech acts are shown to announce the products to the audiences. The three advertisements describe different styles and tones, and then they express several types of speech acts to make these commercials more attractive and entertaining for the audiences.

In brief, copy-writers must select suitable styles and tones for producing advertisements, depending on whether the commercials want to inform, persuade, or entertain, although a single advertisement may perform more than one of these functions (Book and Schick: 1996).

In conclusion, the tones and styles have essential part in advertisements to persuade the audiences. By implementing various tones and styles, the advertisements are expected to be more effective. A number of significant issues from TV advertisements are exposed and may affect the audience whether consciously or not. The three advertisements of two food \& health products and a cell-phone provider have used three specific tones and three different styles. This study has indicated that five types of speech acts based on Searle are expressed in these different tones and styles of advertisements.

The following suggestions are proposed for future study: (1) that this study be replicated using a larger sample to more clearly identify how speech act expression can be effectively explored as a means to enhance students' linguistic notion and comprehension; (2) that a study be undertaken both in various contexts and levels of educations to help students 
in understanding linguistic field, especially speech act expression by considering speech acts are acts of communication.

\section{References}

Altstie, T. and Grow, J. (2006). Advertising Strategy: Creative Tactics from the Outside/In. London: SAGE Publications.

Best, John. (1993). Research in Education. Englewood Cliff: Prentice-Hall.

Book, A. C. and Schick, C. D. (1996). Fundamentals of Copy and Layout. New York: NTC Business Books.

Burgoon, M. and Ruffner M. (1974). Human Communication. USA: Holt, Rinehart, and Winston.

Kleppner, O., Russel, T., and Verril, G. (1986). Advertising Procedure. USA: Prentice Hall, Inc.

Merriam, Sharan B. (1998). Qualitative Research and Case Study Applications in Education. San Fransisco: Jossey-Bass, Inc.

Searle, J. R. (1969). Speech Acts: An Essay in the Philosophy of Language. London: Cambridge.

Yule, G. (1996). Pragmatics. Oxford: Oxford University Press. 